\title{
RELEASE OF METALS FROM CONTAMINATED SEDIMENTS UNDER SIMULATED REDOX CHANGES
}

\author{
L.T. NGUYEN ${ }^{1}$, T. LUNDGREN ${ }^{2}$, K. HÅKANSSON ${ }^{3}$ \& B.H. SVENSSON ${ }^{1}$ \\ ${ }^{1}$ Department of Water \& Environmental Studies, Linköping University, Sweden. \\ ${ }^{2}$ Hifab AB-Envipro Miljöteknik AB, Sweden. \\ ${ }^{3}$ Geo Innova AB, Sweden.
}

\begin{abstract}
This study aimed to examine the consequent release of the metals $\mathrm{Fe}, \mathrm{Zn}, \mathrm{Cu}$ and $\mathrm{Cd}$ from the sediments under simulated redox changes. Two contaminated sediments, 'A' representing the top layer and 'B' representing the deeper layers taken from Lake Håcklasjön downstream of a hydropower plant in southern Sweden, were incubated in the lake water in flow-cells under both anoxic and aerated conditions. Under anoxic conditions, Fe was rapidly released from both sediments (A and B) into the solution, which was likely a result of diffusion from porewater along with the reductive dissolution of hydroxides, whereas the concentrations of dissolved $\mathrm{Zn}$, $\mathrm{Cu}$ and $\mathrm{Cd}$ remained low. The opposite results occurred for all the studied metals during aeration: i.e. precipitation of $\mathrm{Fe}$ and a progressive release of $\mathrm{Zn}, \mathrm{Cu}$ and $\mathrm{Cd}$. The oxidation of ferrous to ferric $\mathrm{Fe}$ was the most likely process responsible for the removal of Fe from the water column from both sediments. Meanwhile the release of the trace metals was probably a result of the oxidation of sulphides, degradation of particulate organic matter or diffusion/advection. The water flow applied during the aeration period likely induced resuspension, which would be a contributing factor to the metal release by enhancing both porewater diffusion/advection and interactions between the resuspended sediments and the overlying water. The decrease in $\mathrm{pH}$ in overlying water of sediment A could be the reason for the faster increase in trace metal concentrations compared to that of sediment $\mathrm{B}$. Copper was probably not affected by $\mathrm{pH}$ change, as $\mathrm{Cu}$ was complexed with dissolved organic carbon and carbonates using the Visual MINTEQ model. The results from the experiment show that aeration of the sediment samples is an important factor for the release of $\mathrm{Zn}, \mathrm{Cu}$ and $\mathrm{Cd}$ into the water column. The low flow of water applied in the experiment compared to that generated by operation periods of the hydropower plant suggests that probably more metals will be released under field conditions.

Keywords: anoxic, aeration, chemical modelling, diffusion, flow-cell, hydropower plant, redox potential, resuspension, sediment, water flow.
\end{abstract}

\section{INTRODUCTION}

Many hydrodynamic processes resulting from e.g. storms, hydropower generation, strong bottom currents and waves may affect the redox conditions of aquatic sediments in lakes and water reservoirs [1,2].The change in redox conditions in turn can strongly influence the mobilization of heavy metals from sediments [3-5]. Under anoxic, i.e. low redox conditions, concentrations of heavy metals in solution are generally low [6-9], because they are usually stable, particularly in sulphidic forms in the sediments [10-12]. Resuspension/mixing processes induced by high-energy processes such as hydropower generation, strong bottom currents, wind or waves in shallow lakes may cause increases in concentrations of $\mathrm{O}_{2}$ in overlying water [13,14]. Diffusion of $\mathrm{O}_{2}$ from the overlying water into bottom sediments creates an oxidized microzone, which may vary in depth, depending inter alia on biological activities, $\mathrm{O}_{2}$-demand $[10,15]$ and strength of resuspension processes [16]. In such oxic environments, the metals that are bound as sulphides under anoxic conditions, can be dissolved within a short time as free ions or be complexed by dissolved organic matter. This may be followed by transport or re-adsorption of the metal ions onto reactive solid surface sites such as freshly precipitated iron/manganese oxides/ hydroxides or biotic materials $[4,17,18]$.

Chemical processes control the release of metal contaminants from sediment into the porewater, while diffusion, advection and mixing of sediments and water at the interface due to bioturbation or 
hydrodynamic forces are reported as the most important transport processes of dissolved substances between sediments and the water column $[15,19,20]$. Under weak hydrodynamical forces near the sediment-water interface, diffusion is the most important mechanism for transport of dissolved substances across the sediment-water interface [21,22]. Under increasing intensity of the disturbance such as resuspension of surface sediments into bottom water, the rate of $\mathrm{O}_{2}$ penetration into the sediments may increase. Together with enhanced diffusion process as a result of increased water-sediment contact a new equilibrium will develop [16,23]. Many studies on oxidation/resuspension of sediments have shown a consequent release of the metals [4, 18, 24-26].

The small town of Åtvidaberg (250 km SE of Stockholm, Sweden) was the centre of a mining district that operated on sulphidic copper ores that dates back to the medieval era, but ended in the beginning of the 20th century. From 1765 to 1903 the town hosted a copper smelter that produced some 900000 tonnes of slag and leaching residues most of which were deposited around the Tail Canal from the smelter. During the last two centuries hundreds of tonnes of zinc, copper and cadmium have been trapped in the sediments of the downstream recipients. Of these Lake Håcklasjön has become an important secondary metal source [27]. Lake Håcklasjön is shallow (ca. 2-2.5 m deep) and eutrophic with elevated concentrations of $\mathrm{Zn}, \mathrm{Cu}, \mathrm{Cd}$ and $\mathrm{Fe}$ in its sediment profile [28]. The lake is directly fed by water from the surrounding cultivated and forested land areas and also from a municipal wastewater treatment plant. However, the main discharge comes from the Tail Canal and via a hydropower plant. During operation periods, the power plant discharges ca. $3.6 \mathrm{~m}^{3} / \mathrm{s}$ (80\% opening aperture) of water into the lake. This corresponds to an average water velocity of about $1 \mathrm{~cm} / \mathrm{s}$ over the lake. This flow rate is supposed to cause resuspension and oxidation of top layers of the lake sediments and therefore, a potential mobilization of the constituents from the sediments. During dry periods (mostly during summers), the hydropower plant operation is closed, which renders the eutrophic lake to become stagnant. This in turn promotes anoxic conditions at the near water-sediment interface.

It could be argued that the increased contact between water and sediments resulting from resuspension or similar hydrodynamic processes will lead to higher adsorption of metals to the suspended matter. However, it could also be argued that resuspension of sediments most probably increases the metal transported in the dissolved phase. In view of this, our working hypothesis is that direct mobilization of elements to the dissolved phase takes place during such physical disturbances of the sediments. In order to differentiate between the two main features of metal transport including the changes in compositions of dissolved constituents and suspended particulate, two set-ups were used. In this study changes in the dissolved phase were examined. In another study with similar objectives [29], batch experiments were carried out to estimate/quantify the metal concentrations in the suspended particulate and the distribution between suspended particulate and dissolved phases, when the lake sediments were resuspended in oxic water.

The main objective of this study was to examine the release of metals during simulation of changes in redox conditions on the water/sediments systems. The release of the redox-sensitive element $\mathrm{Fe}$ and three other metals $-\mathrm{Zn}, \mathrm{Cu}$ and $\mathrm{Cd}-$ from the contaminated lake sediments were studied for: (i) the top $6 \mathrm{~cm}$ (sediment A), and (ii) the deeper 8-12 cm (sediment B). The two sediment layers were separately incubated in flow-cells, where anoxic-static and aerated conditions with a water flow were run in sequence. Physicochemical variables such as $\mathrm{pH}$ and dissolved $(<0.4 \mu \mathrm{m})$ organic carbon (DOC) were also monitored to assess their concomitant changes and their possible influences on the mobilization of the target metals. Redox $\left(E_{\mathrm{h}}\right)$ levels were measured during the aeration period to estimate the influence of diffused $\mathrm{O}_{2}$ at different depths over time. 


\section{MATERIALS AND METHODS}

\subsection{Field sampling}

Twelve sediment cores were collected from Lake Håcklasjön (Fig. 1) using a Kajak corer and placed in acrylic cylinders (8 cm in diameter) in July 2005. The collected cores were overlain with $20 \mathrm{~cm}$ of bottom lake water and the cylinders were sealed with rubber stoppers to avoid intrusion of air. Lake water samples were taken at depths of ca. $1 \mathrm{~m}$ by a water sampler and were stored in a 15-1 plastic carboy. The sediment cores were kept upright and both water and sediment samples were kept cool and airtight during transport to the laboratory. Upon arrival, the lake water and sediment samples were stored in the dark at $4^{\circ} \mathrm{C}$ until processing the next day. The lake water samples were sparged overnight with $\mathrm{N}_{2}$ gas to flush out any residual oxygen.

\subsection{Experimental set-up}

\subsubsection{Flow-cell design}

Flow-cells $(l \times w \times h=36 \times 11 \times 11 \mathrm{~cm})$ with three compartments made of unstained polypropylene were used to incubate the sediments, which were placed in the middle compartment $(22 \times 11 \times 6 \mathrm{~cm}$; Fig. 2). Each flow-cell was connected to a peristaltic pump (Alitea AB, Sweden) via PVC tubing ( $1 \mathrm{~cm}$ in diameter). A $60-\mathrm{ml}$ syringe via a Luer lock to collect overlying water was connected to the tubing. Each flow-cell was sealed with an airtight lid and silicone glue was used to secure that no leaking occurred. The lid of each flow-cell had five holes through which redox electrodes were installed.

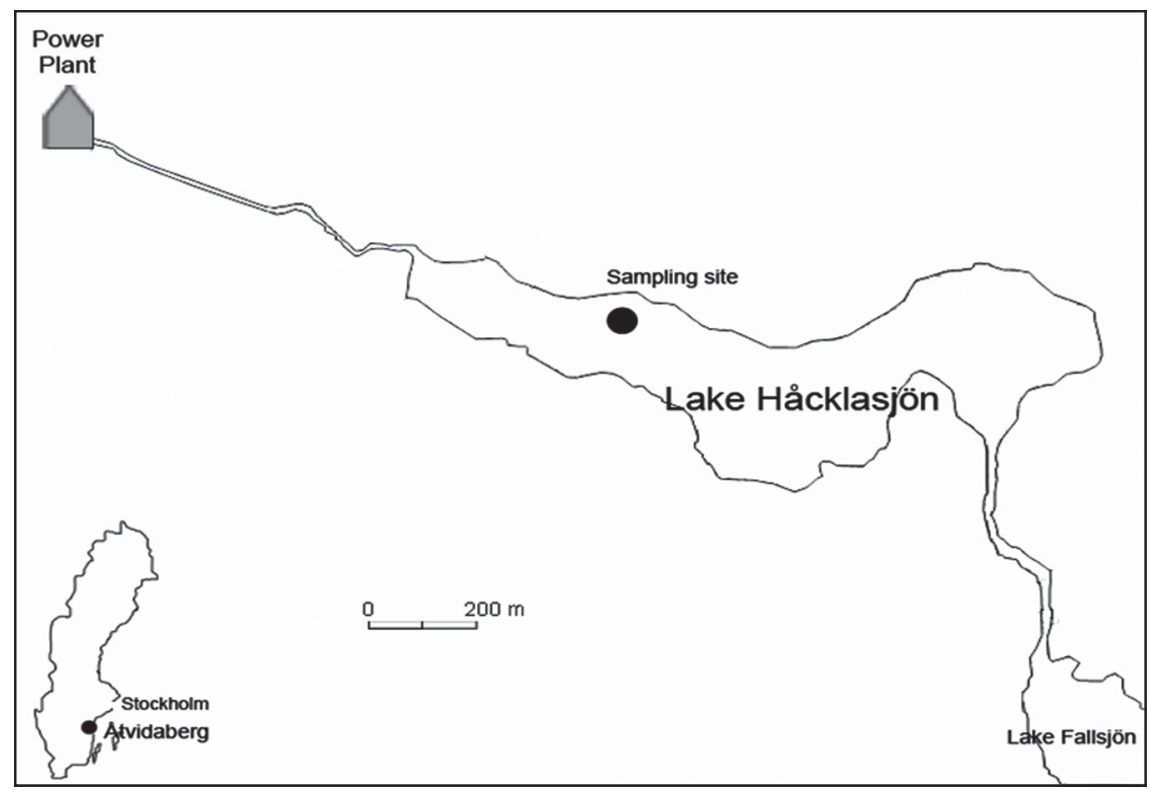

Figure 1: Study area and the sampling site in Lake Håcklasjön (Åtvidaberg). 


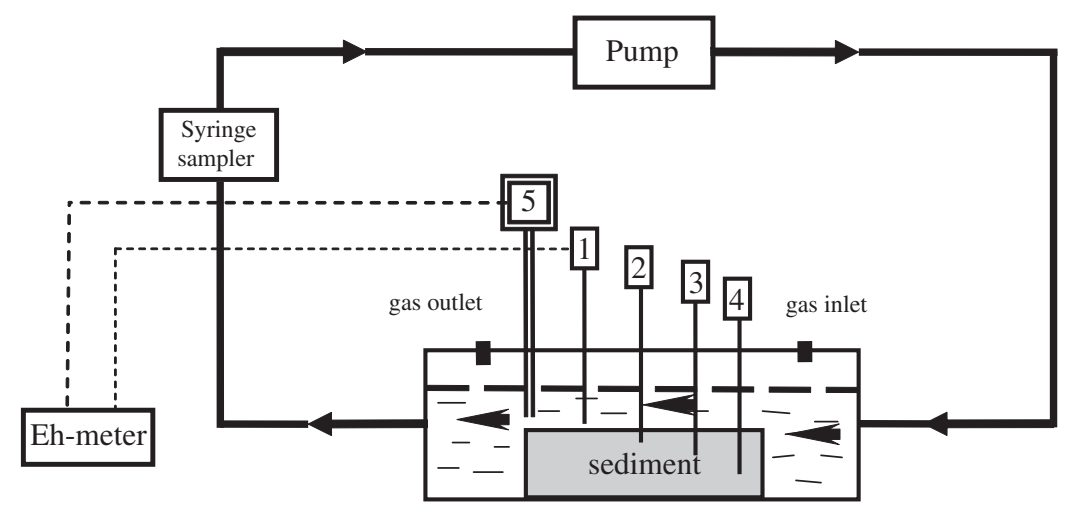

Figure 2: Schematic diagram of the flow-cell. Thin (2 mm dia.) platinum wires (1-4) and calomel reference electrode (5), connected to a standard $E_{\mathrm{h}}$-meter (PHM 83; Radiometer), were inserted in the top layer cell to measure the redox potentials of the overlying water and the sediment at three depths $(0.5-1,1.5-2$ and $3-3.5 \mathrm{~cm})$.

\subsubsection{Experimental procedure}

The water columns overlying the 12 sediment cores were siphoned off, and the cores were sectioned into six slices: $0-0.5,0.5-1.5,1.5-2.5,2.5-4,4-6$ and $8-12 \mathrm{~cm}$ below the sediment surface. The corresponding slices from each of the cores were lumped in airtight $\mathrm{N}_{2}$ pre-filled plastic containers and homogenized. Thus, all 12 slices from the layer $0-0.5 \mathrm{~cm}$ were lumped together and the same procedure was applied for the consecutive layers. A volume of ca. $300 \mathrm{ml}$ of each of the pooled, homogenized slices of the top sediment layer $(0-6 \mathrm{~cm}$; sediment A) was then deposited in the middle compartment of a flow-cell, in reverse depth order (i.e. the deepest slice at the bottom and the successive slice levels towards the top). Approximately 1.51 of the pooled and homogenized deeper layer $(8-12 \mathrm{~cm}$; sediment B) was thoroughly mixed and then placed in the middle compartment of a second flow-cell. The deoxygenated lake water (3.5 1) was then gently poured into each flow-cell to give a water layer of ca. $3 \mathrm{~cm}$ above the sediments. All handling procedures and treatments of the samples samplings were carried out within a glove box, which was continuously flushed with $\mathrm{N}_{2}$ gas, maintaining $\mathrm{O}_{2}$ levels $<0.4 \%$ throughout the procedures.

The flow-cells with sediments A and B were kept anoxic for 21 days by passing a continuous stream $\left(20 \mathrm{ml} / \mathrm{min}\right.$ ) of $\mathrm{N}_{2}$ gas through them (Fig. 2). The $\mathrm{O}_{2}$ levels were $<0.1 \%$ in the gaseous phase as read by a portable oxygen analyser (Servomex $570 \mathrm{~A}$ ). The experiment was run in a climate-controlled chamber at the in situ temperature of $15^{\circ} \mathrm{C}$ in darkness. After 21 days, the conditions were switched to oxic by exchanging the gas phase $\left(\mathrm{N}_{2}\right)$ of the two flow-cells for technical air $(20 \mathrm{ml} / \mathrm{min}$; Air Liquide, Sweden). Furthermore, the overlying water in the two cells was circulated by pumping at an average water velocity of ca. $0.1 \mathrm{~cm} / \mathrm{s}$.

Samples $(60 \mathrm{ml})$ of the overlying water were taken from each cell at six occasions during the anoxic-static period (after $3 \mathrm{~h}, 1,3,4,11$ and 21 days) and at six sampling occasions (after 1, 2, 4, 6, 8 and 11 days) during aeration. At each sampling occasion during the aeration period the pumps were stopped for a while to enable redox readings to be taken. The redox values $\left(E_{\mathrm{h}}\right.$ in $\left.\mathrm{mV}\right)$ were corrected for temperature and $\mathrm{pH}$ following Svensson and Rosswall [30]. Before each sampling occasion during the anoxic phase, the pumps were run at very slow speed $(0.001 \mathrm{~cm} / \mathrm{s})$ for about $10 \mathrm{~min}$ to mix the overlaying water before sampling. After withdrawing overlying water, an 
equivalent volume of filtered lake water (deoxygenated and oxygenated following anoxic and aeration samplings respectively) was returned to the flow-cells to maintain the initial solid/liquid ratio. The dilution effect was negligible and, thus, not accounted for in the reported concentration values.

\subsection{Sample analyses}

All containers and equipment in contact with samples were washed with Milli-Q water, while those for metal analyses were acid-washed before thoroughly rinsed with Milli- $\mathrm{Q}$ water.

\subsubsection{Sediments}

Total contents of $\mathrm{Fe}, \mathrm{Zn}, \mathrm{Cu}$ and $\mathrm{Cd}$ of the residual pooled homogenized sediment slices used in the experiments (after pore-water extraction) were determined using ICP-OES at Al-Control Laboratories (Linköping, Sweden) after aqua regia digestion according to ISO method 15587-1 [31]. Blanks (using Milli-Q water) and certified reference samples (using PACS-2 purchased from the Canadian National Research Council) were prepared in the same way as our sediment samples to evaluate the analytical procedures and the quality of the obtained results. The reproducibility was within $15 \%$ of the certified concentrations for all elements of interest. The concentrations of target elements in the blanks were below the detection limits of the analytical technique used. Water contents of the residual pooled homogenized sediments were determined by drying of sediment samples in an oven at $105^{\circ} \mathrm{C}$ for $24 \mathrm{~h}$, following method SS-EN 12880 [32]. Organic matter contents of the sediments (or, LOI) were determined as loss on ignition (LOI) by incubating the dried sediments in a furnace at $550^{\circ} \mathrm{C}$ for $2 \mathrm{~h}$ according to the method SS 028112 [33].

\subsubsection{Overlying water}

The term 'dissolved' phase in the present study refers to the liquid that passes through a $0.4 \mu \mathrm{m}$ filter, including truly dissolved species and colloids. This means that the 'dissolved' phase is most likely overestimated. However, this cut-off was chosen as it is partly a common practice and enables us to compare our results with those of other studies $[3,19,34]$. The choice of mesh size decreases the risk of clogging above the filter surface, which may cause sorption of dissolved material as compared with finer filter sizes. The samples of overlying water withdrawn from the flow-cells were filtrated through $0.4 \mu \mathrm{m}$ polycarbonate filters (Isopore ${ }^{\mathrm{TM}}$; Millipore) while flushing with $\mathrm{N}_{2}$ to avoid air contamination. Concentrations of dissolved $\mathrm{Fe}, \mathrm{Zn}, \mathrm{Cu}$ and $\mathrm{Cd}, \mathrm{DOC}$ and dissolved inorganic carbon (IC) were determined. All samples for metal determinations were preserved by adding concentrated $\mathrm{HNO}_{3}$ to $\mathrm{pH}<2$ before analysis. The $\mathrm{pH}$ and electrical conductivity of water samples were determined using a PHM 93 pH-meter and a CDM 83 Conductivity-meter (Radiometer, Copenhagen, Denmark) respectively. The water samples for determination of DOC and IC concentrations were stored frozen and then analysed using a Shimazu TOC-5000 analyser. A Perkin-Elmer 1100 Atomic Absorption Spectrometer was used for all metal analyses, in flame mode for Fe and $\mathrm{Zn}$ and in graphite-furnace mode for $\mathrm{Cu}$ and $\mathrm{Cd}$. Blanks were prepared and analysed in the same way as the samples for assessing the validity of the values obtained.

\subsubsection{Pore-water}

Pore-water was extracted from the residual samples of the pooled homogenized sediment slices by centrifuging them in airtight, $\mathrm{N}_{2}$-filled centrifuge tubes at $17700 \times g$ for $10 \mathrm{~min}$. The supernatants were filtered and preserved as above. Portions for metals analysis were prepared and the remainder was stored frozen for later determination of DOC and IC. 


\subsection{Chemical modelling}

Data from the different sampling occasions were analysed with the chemical speciation program Visual MINTEQ version 2.30 [35]. Aqueous speciation was calculated for measured $\mathrm{pH}$ levels. Redox conditions were not used as a parameter in the modelling due to lack of data. Instead concentrations of iron were set as $\mathrm{Fe}(\mathrm{II})$ during anoxia and as $\mathrm{Fe}$ (III) during aeration. A comparison of the lake water concentrations and pore-water concentrations of $\mathrm{Fe}$ shows that the pore-water concentrations were about 1 order of magnitude higher in the pore-water. In the lake water it is possible that $\mathrm{Fe}$ predominantly exist as $\mathrm{Fe}(\mathrm{III})$ bound to organic material. In the sediments, however, such high concentrations of Fe(III) are not possible at the prevailing pH levels. Thus, we used $\mathrm{Fe}$ as $\mathrm{Fe}(\mathrm{II})$ in the thermodynamic calculations for the anoxic experiment. Oversaturated solids were allowed to precipitate when the final solution was achieved. As detailed data on the nature of the organic carbon were not available, the simple organic sub-model according to Grimm et al. [36] was chosen. The major constituents ( $\mathrm{Ca}, \mathrm{Mg}, \mathrm{Na}$ and $\mathrm{K})$, which considerably affect the ion balance, were not analysed in the current experiment. Therefore, they were instead taken from the data of a 5-year surface water-monitoring programme in Lake Håcklasjön during the corresponding period (in July 2005). The values of the main constituents used in the model were $21(\mathrm{Ca}), 2.4(\mathrm{Mg}), 6.8(\mathrm{Na})$ and $2(\mathrm{~K}) \mathrm{mg} / 1$ [27]. The lack of data on sulphur prevented the estimation of any sulphide control of the water chemistry. However, the high concentrations of $\mathrm{Zn}$ and $\mathrm{Cu}$ in the pore-water (Table 1) indicate that sulphide was not controlling the concentrations of trace elements neither in sediment A nor in sediment B. This is reasonable, since the concentrations of e.g. Zn were higher in the presumably more reduced sediment B than in sediment $\mathrm{A}$. High concentrations of $\mathrm{Fe}$ in the pore-water indicate that $\mathrm{Fe}$ at the start of the experiments will be found as $\mathrm{Fe}(\mathrm{II})$.

\section{RESULTS}

\subsection{Physicochemical compositions of original samples used in the experiment}

The eutrophic lake water had a high $\mathrm{pH}$ value, 8.9 (Table 1), probably as a result of high levels of photosynthesis during the sampling period in July. The dissolved concentrations of $\mathrm{Zn}, \mathrm{Cu}$ and $\mathrm{Cd}$ in the lake water were moderately high according to the classification published by the Swedish Environmental Protection Agency, SEPA [37]. Both studied sediments A and B had pH values between 6.8 and 7.1 and organic matter contents (LOI) of 30-33\%. The contents of $\mathrm{Fe}, \mathrm{Zn}, \mathrm{Cu}$ and $\mathrm{Cd}$ in sediments $\mathrm{A}$ and $\mathrm{B}$ were also high according to SEPA [37] confirming that the lake sediments are heavily polluted.

\subsection{Time courses of changes in physicochemical parameters}

After 3-h exposure of the lake water to the sediments, the $\mathrm{pH}$ of the original lake water decreased from 8.9 above both sediments A and B to 7.7 and 8.3 respectively (cf. Table 1 and Fig. 3). During the 21 days of anoxic incubation, the changes in $\mathrm{pH}$ were similar for both sediments, i.e. a gradual decrease to $\mathrm{pH} 7.2$ until day 4, followed by an increase again to between 7.4 and 7.6 during the rest of the anoxia (Fig. 3). However, following the shift to aerated conditions, $\mathrm{pH}$ in sediment $\mathrm{A}$ decreased from 7.6 to 6.9 , whereas $\mathrm{pH}$ in sediment $\mathrm{B}$ rose from 7.5 to 8 and then decreased to 7.6 .

The concentration of dissolved IC gradually more than doubled above both sediments A and B during anoxia (Fig. 3). In contrast, during the first 2 days of aeration the IC concentrations rapidly 


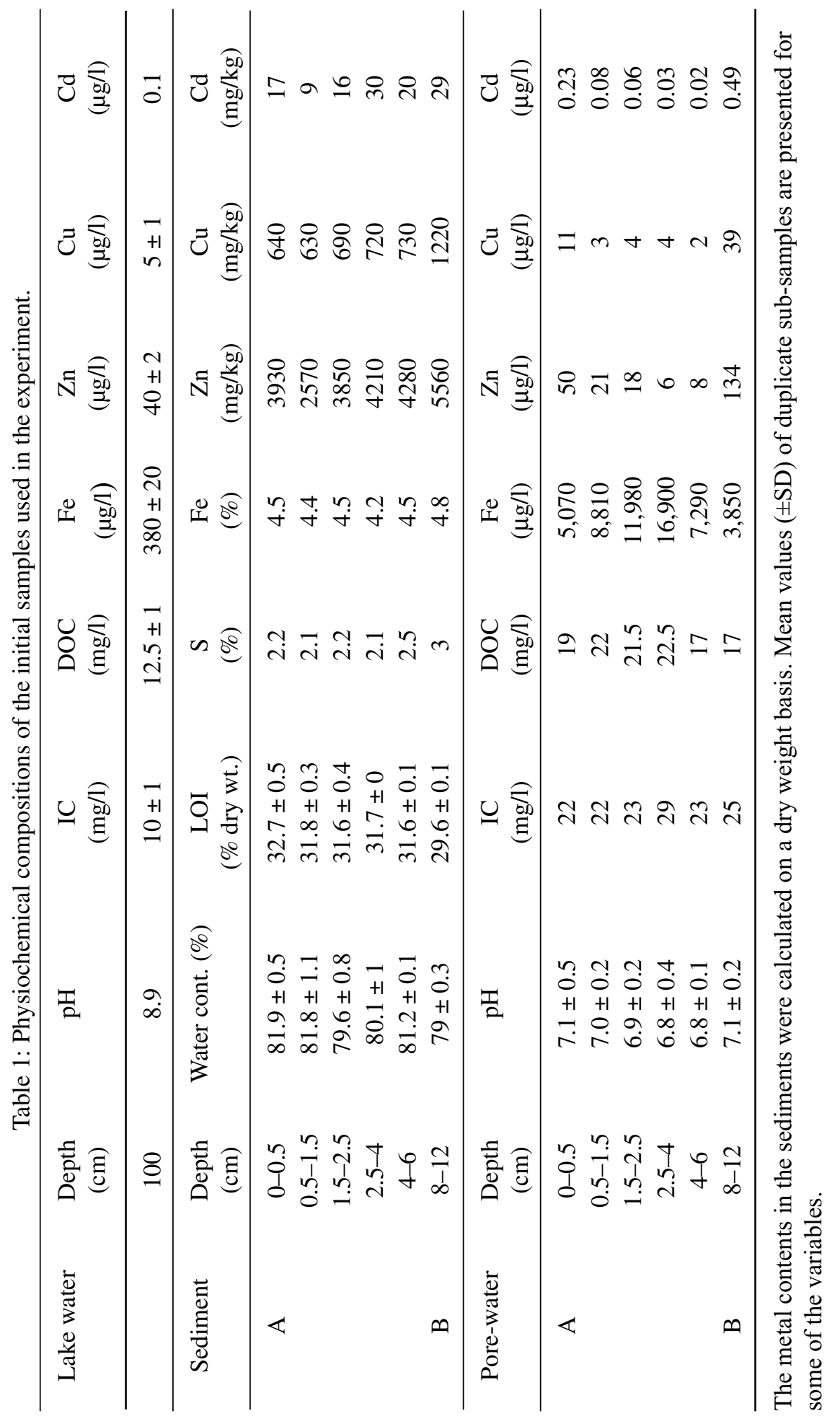



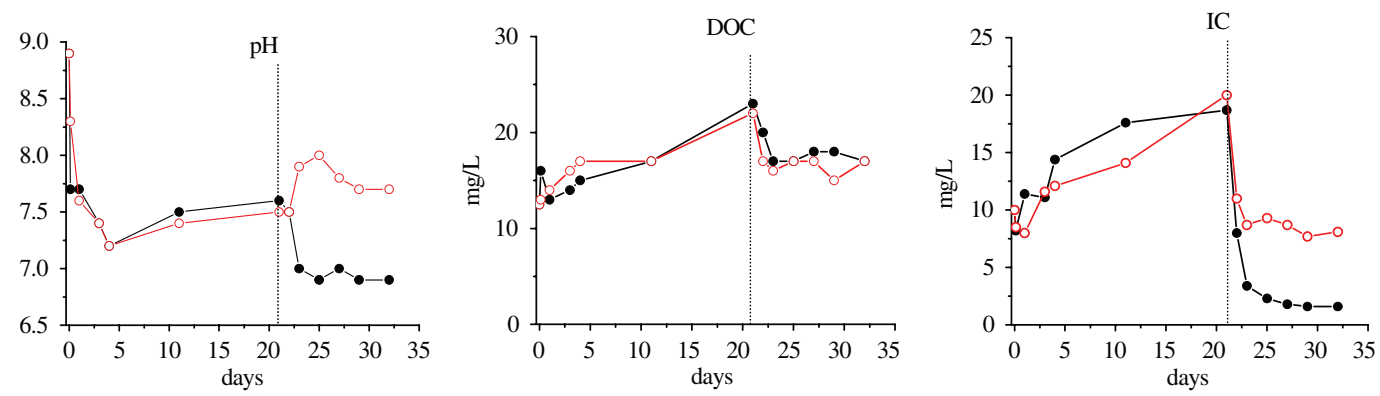

Figure 3: Time courses of changes in $\mathrm{pH}$, dissolved organic carbon (DOC) and inorganic carbon (IC) for sediment A $(\bullet)$ and sediment B $(\bullet)$ during the 32-day experiment. Vertical dashed lines indicate the end of the anoxic-calm period and beginning of the aeration phase.

Table 2: Redox changes $(\mathrm{mV})$ in overlying water and at three depths of sediment A during aeration.

\begin{tabular}{lccccccc}
\hline & Depth $(\mathrm{cm})$ & Day 22 & Day 23 & Day 25 & Day 27 & Day 29 & Day 32 \\
\hline Overlying water & 1 & - & 420 & 480 & 460 & 440 & 410 \\
Sediment A profile & $0.5-1$ & - & 150 & 190 & 170 & 250 & 250 \\
& $1.5-2$ & - & -150 & 120 & 160 & 340 & 340 \\
& $3-3.5$ & - & -350 & -280 & -270 & -60 & -80 \\
\hline
\end{tabular}

$-=$ not determined; no redox measurement was unfortunately performed on sediment $B$. The aeration period started from day 22 to day 32 of the experiment. The redox values were corrected for temperature and $\mathrm{pH}$ according to Svensson and Rosswall. [30].

dropped for both sediments and subsequently remained stable during the remainder of the experiment. Similarly, the concentrations of DOC above both sediments increased over 21 days of anoxia. However, it rapidly decreased during the first 2 days of aeration, from about 23 to $16 \mathrm{mg} / \mathrm{l}$ and remained relatively constant at this level within the rest of the aeration episode.

It was not possible to record the $E_{\mathrm{h}}$ values during the anoxic-static period and the first sampling occasion of the aeration phase. However, after 1 day of aeration (i.e. day 23 of the 32-day experiment), the $E_{\mathrm{h}}$ of the overlying water was recorded at $+420 \mathrm{mV}$ and it subsequently remained relatively stable, ranging between +480 and $+410 \mathrm{mV}$, during the rest of the aeration phase (Table 2). The $E_{\mathrm{h}}$ values of sediment $A$ at three depths $(0.5-1,1.5-2$ and $3-3.5 \mathrm{~cm})$ gradually increased from day 23 to day 29 and remained stable till the end of aeration (day 32). The redox potentials in sediment A appeared to be stabilized after 8 days of oxygenation.

\subsection{Time courses of changes in the concentrations of $\mathrm{Fe}, \mathrm{Zn}, \mathrm{Cu}$ and $\mathrm{Cd}$}

After 3-h exposure of sediments A and B to the deoxygenated lake water, an increase in dissolved Fe concentrations in the overlying water was observed for sediment $\mathrm{A}$, while dissolved $\mathrm{Fe}$ amounts remained constant for sediment B (Table 1 and Fig. 4). Overall, similar patterns of increases in the concentration of dissolved $\mathrm{Fe}$ were observed in both sediments $\mathrm{A}$ and $\mathrm{B}$ throughout the 21-day anoxia. The dissolved $\mathrm{Fe}$ concentrations increased 7-fold for sediment $\mathrm{A}$ and 3-fold 

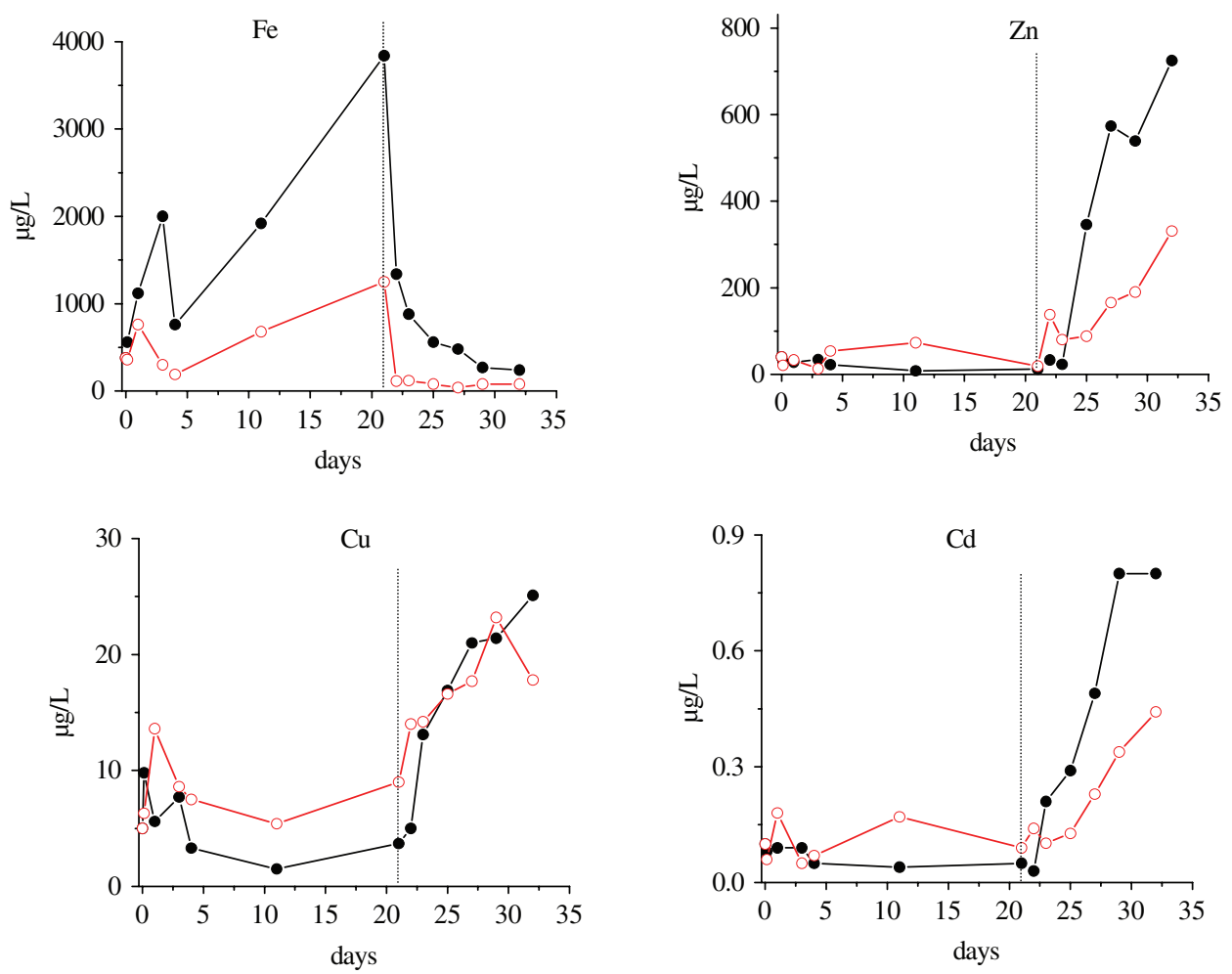

Figure 4: Time courses of changes in dissolved $\mathrm{Fe}, \mathrm{Zn}, \mathrm{Cu}$ and $\mathrm{Cd}$ concentrations in sediments $\mathrm{A}(\bullet)$ wand $\mathrm{B}(\bullet)$ during the 32-day experiment. Vertical dashed lines indicate the end of the anoxic-calm period and beginning of the aeration phase.

for sediment B during the anoxic period. However, 1 day after shifting to aerated conditions, a rapid decrease in dissolved Fe concentrations was recorded in the overlaying water of both sediments. After 1 day of aeration, the dissolved concentrations of Fe in the water from sediment B were used up and levelled off during the rest of the aeration, whereas that for sediment A levelled off after 8 days of oxygenation. However, the dissolved $\mathrm{Fe}$ concentrations decreased 16-fold in both sediment experiments $\mathrm{A}$ and $\mathrm{B}$.

After 3-h exposure of deoxygenated lake water to the sediments, the concentrations of dissolved $\mathrm{Zn}$ in the overlying water had decreased for both sediment A and B (Table 1 and Fig. 4). Meanwhile, the concentrations of dissolved $\mathrm{Cu}$ in the overlying water increased for sediment $\mathrm{A}$, but remained constant for sediment B. For Cd, the dissolved fractions in the water column stayed constant after 3-h exposure. Within the 21-day anoxic-calm conditions, the dissolved concentrations of $\mathrm{Zn}, \mathrm{Cu}$ and $\mathrm{Cd}$ became lower than the initial levels of the lake water with sediment A. However, with sediment B the concentrations of dissolved $\mathrm{Zn}, \mathrm{Cu}$ and $\mathrm{Cd}$ fluctuated between 15-70, 5-15 and ca. 0.1-0.2 $\mu \mathrm{g} / \mathrm{l}$ respectively. During the onset of the aeration period, the concentrations of $\mathrm{Zn}, \mathrm{Cu}$ and $\mathrm{Cd}$ of both sediments rapidly increased. The dissolved concentrations of $\mathrm{Cu}$ and $\mathrm{Cd}$ in the flow-cell with sediment A increased, 7- and 16-fold, respectively, and that of $\mathrm{Zn}$ increased up to 60-fold. The dissolved concentrations of $\mathrm{Cu}, \mathrm{Cd}$ and $\mathrm{Zn}$ also increased in the flow-cell with sediment $\mathrm{B}$, but to lower extents: 3-, 5- and 17-fold respectively. 
Table 3: Calculation of percentage speciation of the precipitated and dissolved constituents during the 21-day anoxic-static and the 11-day aeration for $\mathrm{Fe}, \mathrm{Zn}, \mathrm{Cu}$ and $\mathrm{Cd}$ by Visual MINTEQ model.

\begin{tabular}{|c|c|c|c|c|c|c|c|c|c|c|c|c|c|}
\hline \multirow{2}{*}{\multicolumn{2}{|c|}{ Sampling day }} & \multicolumn{6}{|c|}{ Anoxic } & \multicolumn{6}{|c|}{ Aeration } \\
\hline & & $3 \mathrm{~h}$ & 1 & 3 & 4 & 11 & 21 & 22 & 23 & 25 & 27 & 29 & 32 \\
\hline \multicolumn{14}{|c|}{$\%$ of precipitated cations } \\
\hline \multirow[t]{2}{*}{ Sediment A } & $\begin{array}{l}\text { Siderite, } \\
\mathrm{FeCO}_{3}(\mathrm{~s})\end{array}$ & & & & & 33 & 75 & & & & & & \\
\hline & $\begin{array}{l}\text { Haematite, } \\
\mathrm{Fe}_{2} \mathrm{O}_{3}(\mathrm{~s})\end{array}$ & & & & & & & 100 & 100 & 100 & 100 & 100 & 100 \\
\hline \multirow[t]{2}{*}{ Sediment B } & $\begin{array}{l}\text { Siderite, } \\
\mathrm{FeCO}_{3}(\mathrm{~s})\end{array}$ & & & & & & 8 & & & & & & \\
\hline & $\begin{array}{l}\text { Haematite, } \\
\mathrm{Fe}_{2} \mathrm{O}_{3}(\mathrm{~s})\end{array}$ & & & & & & & 100 & 100 & 100 & 100 & 100 & 100 \\
\hline \multicolumn{14}{|c|}{$\%$ of dissolved species } \\
\hline \multirow[t]{9}{*}{ Sediment A } & $\mathrm{Zn}^{+2}$ & 67 & 71 & 73 & 73 & 67 & 60 & 66 & 73 & 73 & 72 & 72 & 74 \\
\hline & ZnDOM & 23 & 19 & 22 & 23 & 24 & 30 & 29 & 27 & 26 & 27 & 27 & 26 \\
\hline & $\mathrm{ZnCO}_{3}(\mathrm{aq})$ & 5 & 5 & 3 & 2 & 5 & 6 & 2 & - & - & - & - & - \\
\hline & $\mathrm{Cu}^{+2}$ & 6 & 6 & 8 & 8 & 6 & 4 & 6 & 9 & 10 & 9 & 9 & 10 \\
\hline & CuDOM & 47 & 42 & 59 & 65 & 50 & 52 & 69 & 86 & 87 & 87 & 88 & 87 \\
\hline & $\mathrm{CuCO}_{3}(\mathrm{aq})$ & 38 & 46 & 29 & 23 & 41 & 40 & 21 & 3 & 2 & 2 & 2 & 2 \\
\hline & $\mathrm{Cd}^{+2}$ & 79 & 82 & 82 & 81 & 78 & 72 & 77 & 81 & 81 & 81 & 81 & 82 \\
\hline & CdDOM & 17 & 14 & 15 & 16 & 18 & 23 & 21 & 19 & 18 & 19 & 19 & 18 \\
\hline & $\mathrm{CdCO}_{3}(\mathrm{aq})$ & 2 & 2 & 1 & 1 & 2 & 3 & 1 & - & - & - & - & - \\
\hline \multirow[t]{9}{*}{ Sediment B } & $\mathrm{Zn}^{+2}$ & 49 & 72 & 71 & 71 & 70 & 62 & 64 & 64 & 61 & 66 & 70 & 68 \\
\hline & ZnDOM & 14 & 21 & 24 & 26 & 25 & 30 & 31 & 22 & 22 & 24 & 22 & 24 \\
\hline & $\mathrm{ZnCO}_{3}(\mathrm{aq})$ & 12 & 3 & 3 & 2 & 3 & 5 & 3 & 6 & 7 & 5 & 4 & 4 \\
\hline & $\mathrm{Cu}^{+2}$ & 3 & 7 & 7 & 8 & 7 & 5 & 5 & 5 & 4 & 5 & 6 & 6 \\
\hline & CuDOM & 18 & 55 & 61 & 71 & 60 & 55 & 66 & 41 & 37 & 47 & 52 & 55 \\
\hline & $\mathrm{CuCO}_{3}(\mathrm{aq})$ & 67 & 32 & 28 & 19 & 30 & 38 & 26 & 47 & 51 & 41 & 36 & 34 \\
\hline & $\mathrm{Cd}^{+2}$ & 77 & 82 & 80 & 80 & 79 & 73 & 75 & 79 & 77 & 78 & 81 & 79 \\
\hline & CdDOM & 13 & 15 & 17 & 18 & 18 & 22 & 23 & 17 & 18 & 18 & 16 & 18 \\
\hline & $\mathrm{CdCO}_{3}(\mathrm{aq})$ & 8 & 1 & 1 & 1 & 1 & 2 & 1 & 3 & 4 & 2 & 2 & 2 \\
\hline
\end{tabular}

$-=0.5 \% ; \mathrm{DOM}=$ dissolved organic matter.

\subsection{Speciation of the metals by Visual MINTEQ}

The calculated results from the modelling (Table 3) show that the species that reached saturation at the last day of the anoxic-static phase (day 21) were siderite $\left(\mathrm{FeCO}_{3}\right)$ for both sediments A and $\mathrm{B}$. During the aeration phase, precipitation of $\mathrm{Fe}$ as haematite $\left(\mathrm{Fe}_{2} \mathrm{O}_{3}\right)$ was predicted by the model. The precipitation of Fe may be overestimated, since no organic species were defined for Fe by the model. Only the dominating dissolved species for $\mathrm{Zn}, \mathrm{Cu}$ and $\mathrm{Cd}$ during the 32-day experiment are presented in Table 3. The distribution of aqueous species for $\mathrm{Cu}$ was different from those for $\mathrm{Zn}$ and $\mathrm{Cd}$ in that the free metal 
ions of $\mathrm{Cu}$ ( $10 \%)$ were much lower than those of $\mathrm{Zn}(49-74 \%)$ and $\mathrm{Cd}(72-82 \%)$. Further, organic species of $\mathrm{Cu}(\mathrm{Cu}-\mathrm{DOM}, 18-88 \%)$ were more abundant than that of $\mathrm{Zn}$ (Zn-DOM, 14-31\%) and Cd (Cd-DOM, $13-23 \%)$. Another difference was that aqueous carbonate species were more important for $\mathrm{Cu}(2-67 \%)$ than for $\mathrm{Zn}(0.5-12 \%)$ and $\mathrm{Cd}(0.5-8 \%)$.

\section{DISCUSSION}

\subsection{Anoxic-static conditions}

The increase in dissolved $(<0.4 \mu \mathrm{m})$ concentrations of Fe in the overlaying water for both sediments A and $\mathrm{B}$ during anoxic-static conditions was likely caused by diffusion of dissolved Fe from the pore-water. The differences in the release of Fe between sediments A and B could be explained by the higher consolidation (age) of sediment $\mathrm{B}$, but the difference in original porewater concentrations is a more likely explanation. The fluxes of solutes from sediments into the overlying water could be predicted based mainly on concentration gradients between pore-water and overlying water $[9,19,38]$. The fluxes of dissolved Fe were roughly estimated using Fick's First Law according to Metzger et al. [39], Sunby et al. [15] and Li and Gregory [40]. The calculations predicted a flux of Fe from sediment A ranging $2.1-3.6 \mathrm{mg} / \mathrm{m}^{2} /$ day and from sediment $\mathrm{B}$ of about $1-1.5 \mathrm{mg} / \mathrm{m}^{2} /$ day into the water column during the anoxic-static conditions. The calculations were based upon the area of sediment $\left(242 \mathrm{~cm}^{2}\right)$ exposed to the overlying water in flow-cell, the period of anoxic phase (21 days) and volume of overlying water used in the flow-cell (3.5 l) and the assumption that the pore-water concentration of elements was constant throughout the anoxic period. It was also assumed that the diffusion could occur down to $2.5 \mathrm{~cm}$ sediment depth (cf. Table 2), thus, the mean pore-water concentration values of $0-2.5 \mathrm{~cm}$ sediment depths were used in the calculation. The flux calculations show that the amount of $\mathrm{Fe}$ released varied between 0.3 and $0.5 \mathrm{mg} / \mathrm{l}$, corresponding to $13 \%$ as due to diffusion from sediment A and between 0.1 and $0.2 \mathrm{mg} / \mathrm{l}$ corresponding to $22 \%$ from diffusion in sediment $\mathrm{B}$ during the 21 anoxic days. The choice of the depth gradient over which to apply the flux estimation using Fick's First Law appears to be the largest error in these types of flux calculations [41] Thus, this would result in a possible underestimation of the Fe fluxes into the overlying water in this study. However, the above calculated fluxes suggest that diffusion from pore-water was a transport process contributing to the increased concentrations of $\mathrm{Fe}$ in the water column during the anoxic period for both sediments.

In general, reduced conditions favour the dissolution of Fe oxides/hydroxides through the microbial decomposition of organic compounds [5, 42-44]. The increase in the DOC concentrations recorded during the 21-day anoxia for both sediments may serve as an indication of such microbial activity. Thus, the occurrence of such dissolution reactions in the sediments likely resulted in a supply of dissolved Fe to the pore-water medium and subsequent upward diffusion of Fe into the overlaying water. The same reactions may also have occurred in the suspended particles in the water column. It is well documented that $\mathrm{Fe}$ in both ferrous and ferric forms can be complexed with dissolved organic matter, which would render Fe to stay longer in the solution [6, 45]. However, the calculated Pearson's correlation did not reveal any significant correlation between the increase in dissolved Fe and DOC concentrations for sediment A or sediment B. Moreover, the result from the modelling did not reveal any Fe complexation with organic solutes during the anoxic phase. Rather iron carbonate $\left(\mathrm{FeCO}_{3}\right.$, siderite) occurred as a solubility-limiting solid phase for Fe at the end of the anoxic episode (Table 3). This indicates that DOC was most likely not a factor contributing to the increase in dissolved Fe in our experiments.

Generally it is expected that dissolved concentrations of $\mathrm{Zn}, \mathrm{Cu}$ and $\mathrm{Cd}$ are much lower during anoxic conditions at neutral $\mathrm{pH}$ than during oxidized environments, which is due to the formation/ precipitation of metal sulphides $[3,7,46,47]$. In our experiment, however, it is evident that the trace 
metal concentrations in the pore-water of sediment A did not differ much from the corresponding concentrations in the original lake water (Table 1), while the porewater concentrations of the trace metals in sediment B were much higher than that in the lake water. If sulphides were controlling the metal concentrations in the sediments, one would expect lower concentrations than the levels that actually were measured in pore-water of the two sediments A and B. The ratio sulphur/metals shows the highest values in sediment B. Therefore, it is unlikely that sulphides in the pore-water phase had regulated the trace metal concentrations via metal sulphide formation/precipitation. This altogether indicates that sulphides may not have controlled the trace metal concentrations in the two sediments. Other studies have also shown that sulphides are not the only possible phase governing the trace metal concentrations. For examples, Naylor et al. [48], who studied the availability of metals in sulphidic sediments, concluded that $\mathrm{Fe}, \mathrm{Zn}$ and $\mathrm{Cu}$ that prevailed in their studied sediments were oversaturated with respect to their sulphides. However, there was also an appreciable fraction of the trace metals associated with Fe/Mn oxides/hydroxides in their sediments. In another study of the relationship between sulphides and metals in sediments in an eutrophic estuary in south-east Brazil, Machado et al. [25] found a difference between river sediments and estuarine sediments in the regulation of trace metal concentrations.

\subsection{Aeration conditions}

The redox values measured after 2 days of aeration in both the overlying water and the uppermost $0-0.5 \mathrm{~cm}$ of sediment A show that an almost immediate oxygenation had taken place. The change in redox values down to the $3-3.5 \mathrm{~cm}$ sediment layer after 11 days of aeration implies that oxidation and precipitation of $\mathrm{Fe}$ would occur down to this depth. The sharp decrease in dissolved Fe after 1 day of oxic conditions for both sediments A and B was most likely a result of a fast oxidation followed by subsequent precipitation of iron oxides/hydroxides. The fast abiotic and biotic oxidation of ferrous to ferric $\mathrm{Fe}$ in the presence of $\mathrm{O}_{2}$ is a well-known phenomenon as reported by Stumm and Lee [49], Stumm and Morgan [50], James and Ferris [51] and Jones-Lee and Lee [52]. Similar observations on the depletion of dissolved Fe in the water column were also reported by Sunby et al. [15], Laima et al. [14] and Miao et al. [8] as a result of switching the water/sediment systems from anoxic to oxic conditions.

The difference in response of dissolved Fe between sediment $\mathrm{A}$ and sediment $\mathrm{B}$ at the start of the oxic conditions is probably explained by the difference in $\mathrm{pH}$. The 1 unit lower $\mathrm{pH}$ in overlying water of sediment A compared to that of sediment B would lead to a lower oxidation rate of $\mathrm{Fe}$ in sediment A [50]. This would explain the presence of higher Fe concentrations remaining in the overlying water of the B sediment during the whole 11-day aeration. The Visual MINTEQ model predicted haematite $\left(\mathrm{Fe}_{2} \mathrm{O}_{3}\right)$ as the dominant precipitating phases for $\mathrm{Fe}$ in both sediments (Table 3); however, other hydrous ferric oxides could also have precipitated during this period.

In contrast to iron, a rapid release of zinc, copper and cadmium occurred in both sediments A and B, which is probably induced by different processes such as oxidation of metal sulphides $[10,12,46]$, degradation of organic particulates [53], dissolution of Fe/Mn oxides/hydroxides and porewater diffusion/ advection $[9,23,38]$. The water flow applied during the aeration period could have induced some resuspension (not measured in this study), which would then be a contributing factor to the release of the metals by enhancing both porewater diffusion/advection and interactions between the resuspended sediments and the overlying water. The increase in dissolved $\mathrm{Zn}$ and $\mathrm{Cd}$ was more rapid for sediment A than for sediment $\mathrm{B}$, while $\mathrm{Cu}$ was released in similar patterns from both sediments. As discussed above (cf. Section 4.1), the ratio sulphur/metals shows the highest values in sediment B, i.e. higher metal contents ( $\mathrm{Zn}$ and $\mathrm{Cd}$ ) and $\mathrm{S}$ contents compared with sediment A. However, less dissolved metals were released on the last day (day 32; cf. Table 1 and Fig. 4). This suggests that oxidation of metal 
sulphides was not the most probable mechanism for releasing the metals during aeration in any of the two sediments. The 1 unit lower $\mathrm{pH}$ in overlying water of sediment $\mathrm{A}$ than in that of sediment $\mathrm{B}$ could be a possible explanation for the different release patterns of $\mathrm{Zn}$ and $\mathrm{Cd}$ via desorption of the metals from the resuspended sediments [28, 54-57]. This is supported by Pearson correlation analysis showing a correlation between the decrease in $\mathrm{pH}$ and the increase in $\mathrm{Zn}(r=-0.72, P<0.05, n=7)$, $\mathrm{Cu}(r=-0.91, P<0.01, n=7)$ and $\mathrm{Cd}(r=-0.76, P<0.05, n=7)$ for sediment A, whereas no correlation was found for sediment $\mathrm{B}$. The possible effects of a resuspension during the circulation of the overlaying water during the aeration period may have affected the difference in concentration for these three metals as was indicated for Fe above.

The lack of correlations between the release of DOC and the increased concentrations of $\mathrm{Zn}, \mathrm{Cu}$ and $\mathrm{Cd}$ in overlying water of both sediments $\mathrm{A}$ and $\mathrm{B}$ during aeration indicates that these metals were not likely associated with organic solute. However, they could be released during the degradation of particulate organic materials [53] and, thus, partly contribute to the increase in dissolved concentrations of these metals in this experiment. The results from Visual MINTEQ modelling, however, predicted the associations of organic solute with $\mathrm{Zn}, \mathrm{Cd}$ and $\mathrm{Cu}$, of which the majority of $\mathrm{Cu}$ was associated with dissolved organic matter in both sediments (Table 3). It is well documented from previous studies that the binding of $\mathrm{Cu}$ to organic material is stronger than for $\mathrm{Zn}$ or $\mathrm{Cd}$ matter [58]. This suggests that DOC was associated with dissolved $\mathrm{Cu}$ in the water column, but not with $\mathrm{Zn}$ and $\mathrm{Cd}$. The model also calculated that carbonate was the dominating species for $\mathrm{Cu}$, but not for $\mathrm{Zn}$ and $\mathrm{Cd}$. The two dominating species for $\mathrm{Cu}$ (i.e. $\mathrm{Cu}-\mathrm{DOM}$ and $\mathrm{CuCO}_{3}$ (eq.)) are not charged and, thus, not affected by a change in $\mathrm{pH}$. This in turn means that the $\mathrm{pH}$ difference of overlying water between the two sediments may not have influenced the release patterns of $\mathrm{Cu}$.

\section{CONCLUSIONS}

Different pictures of the interacting processes between the sediment and the lake water under different redox conditions can be described from the current experimental results. Under anoxic-static conditions, the rapid release of Fe into overlying water in both sediments is most likely a result of the diffusion of $\mathrm{Fe}$ (II) from the porewater as supported by a reductive dissolution of Fe oxides/hydroxides. In contrast to $\mathrm{Fe}, \mathrm{Zn}, \mathrm{Cu}$ and $\mathrm{Cd}$ remained low during the anoxic period. Under aeration conditions $\mathrm{Fe}$ (II) diffusing into oxic parts of the sediment or reaching the oxygenated water column will rapidly oxidize to $\mathrm{Fe}$ (III) with subsequent precipitation of $\mathrm{Fe}$ as haematite $\left(\mathrm{Fe}_{2} \mathrm{O}_{3}\right)$ as predicted by the Visual MINTEQ model. The faster decrease in dissolved $\mathrm{Fe}$ in sediment $\mathrm{B}$ could be a result of the 1 unit higher $\mathrm{pH}$ compared to sediment $\mathrm{A}$. In contrast to $\mathrm{Fe}, \mathrm{Zn}, \mathrm{Cu}$ and $\mathrm{Cd}$ were released during oxygenation, which probably resulted from the degradation of particulate organic matter, oxidation of metal sulphide or dissolution of Fe/Mn oxides/hydroxides. The water flow applied during the aeration period could have induced resuspension (not measured in this study), which is more likely the contributing factor to the metal release through enhancing both pore-water diffusion/advection and interactions between the resuspended sediments and the overlying water. The 1 unit lower $\mathrm{pH}$ in the overlying water of sediment A relative to that of sediment $\mathrm{B}$ could explain the more rapid release of $\mathrm{Zn}, \mathrm{Cu}$ and $\mathrm{Cd}$ from sediment A through the metal desorption from suspended particles. Copper may not be affected by $\mathrm{pH}$ change as $\mathrm{Cu}$ is predicted by Visual MINTEQ to be in the form of complexes with organic solutes and carbonates, which are not influenced by a change in $\mathrm{pH}$.

The results from the experiments show that aeration of sediment samples is an important factor for the release of $\mathrm{Zn}, \mathrm{Cu}$ and $\mathrm{Cd}$ into the water column. In the flow-cell experiment, the supply of oxygen to the streaming water was high and resulted in a significant release of metals into the water phase. Even if the supply of oxygen to the water is less under field conditions, an increase in the mobilization of metals would be expected as a result of increased aeration of the water overlaying 
the lake sediments. The water velocity applied during the aeration period of our experiment was about 1 order of magnitude lower than that generated during the operation of the hydropower plant. Thus, the release observed is likely an underestimation compared to field conditions. Furthermore, resuspension mechanisms are suggested to increase the exchange of metals between the sediments and the water column, which will be addressed in a later study on the Lake Håcklasjön sediments.

\section{REFERENCES}

[1] Arfi, R., Seasonal ecological changes and water level variations in the Selingue reservoir (Mali, West Africa). Physics and Chemistry of the Earth, 30, pp. 432-441, 2005.

[2] Catallo, W.J. \& Junk, T., Effects of static vs. tidal hydrology on pollutant transformation in wetland sediments. Journal of Environmental Quality, 32, pp. 2421-2427, 2003.

[3] Caille, N., Tiffreau, C., Leyval, C. \& Morel, J.L., Solubility of metals in an anoxic sediment during prolonged aeration. The Science of the Total Environment, 301, pp. 239-250, 2003.

[4] Eggleton, J. \& Thomas, K.V., A review of factors affecting the release and bioavailability of contaminants during sediment disturbance events. Environment International, 30, pp. 973-980, 2004.

[5] Guo, T., Delaune, R.D. \& Patrick Jr, W.H., The effect of sediment redox chemistry on solubility/ chemically active forms of selected metals in bottom sediment receiving produced water discharge. Spill Science \& Technology Bulletin, 4(3), pp. 165-175, 1997.

[6] Hamilton-Taylor, J., Davison, W. \& Morfett, K., The biogeochemical cycling of $\mathrm{Zn}, \mathrm{Cu}, \mathrm{Fe}$, $\mathrm{Mn}$ and dissolved organic $\mathrm{C}$ in a seasonally anoxic lake. Limnology and Oceanography, 41, pp. 408-418, 1996.

[7] Lu, J.C.S. \& Chen, K.Y., Migration of trace metals in interfaces of seawater and polluted surficial sediments. Environmental Science \& Technology, 11(2), pp. 174-182, 1977.

[8] Miao, S., DeLaune, R.D. \& Jugsujinda, A., Influence of sediment redox conditions on release/ solubility of metals and nutrients in a Louisiana Mississippi river deltaic plain freshwater lake. Science of the Total Environment, 371, pp. 334-343, 2006.

[9] Westerlund, S.F.G., Anderson, L.G., Hall, P.O.J., Iverfeldt, Å., van der Loeff, R.M.M. \& Sunby, B., Benthic fluxes of cadmium, copper, nickel, zinc and lead in the coastal environment. Geochimica Cosmochimica Acta, 50, pp. 1289-1296, 1986.

[10] Calmano, W., Hong, J. \& Förstner, U., Binding and mobilization of heavy metals in contaminated sediments affected by $\mathrm{pH}$ and redox potential. Water Science \& Technology, 28(8-9), pp. 223-235, 1994.

[11] Cooper, D.C. \& Morse, J.W., Selective extraction chemistry of toxic metal sulfides from sediments. Aquatic Chemistry, 5, pp. 87-97, 1999.

[12] Simpson, S.L., Apte, S.C. \& Batley, G.E., Effect of short-term resuspension events on the oxidation of cadmium, lead, and zinc sulphide phases in anoxic estuarine sediments. Environmental Science and Technology, 34, pp. 4533-4537, 2000.

[13] Bengtsson, L. \& Hellström, T., Wind-induced resuspension in a small shallow lake. Hydrobiologia, 241, pp. 163-172, 1992.

[14] Laima, M.J.C., Matthiesen, H., Lund-Hansen, L.C. \& Christiansen, C., Resuspension studies in cylindrical microcosms: effects of stirring velocity on the dynamics of redox-sensitive elements in a coastal sediment. Biogeochemistry, 43, pp. 293-309, 1998.

[15] Sunby, B., Anderson, L.G., Hall, P.O.J., Iverfeldt, Å., van der Loeff, R.M.M. \& Westerlund, S.F.G., The effect of oxygen on release and uptake of cobalt, manganese, iron and phosphate at the sediment-water interface. Geochimica Cosmochimica Acta, 50, pp. 1281-1288, 1986. 
[16] Falter, J.L. \& Sansone, F.J., Hydraulic control of pore water geochemistry within the oxic-suboxic zone of a permeable sediment. Limnological Oceanography, 45 (3), pp. 550-557, 2000.

[17] Calmalo, W., Ahlf, W. \& Förstner, U., Exchange of heavy metals between sediment components and water. Metal Speciation in the Environment, eds J.A.C. Broekaert, S. Gucer \& F. Adams, Springer-Verlag: Berlin, pp. 503-522, 1990.

[18] Di Nanno, M.P., Curutchet, G. \& Ratto, S., Anaerobic sediment potential acidification and metal release risk assessment by chemical characterization and batch resuspension experiments. Journal of Soils \& Sediments, 7(3), pp. 187-194, 2007.

[19] Caetano, M., Madureira, M.-J. \& Vale, C., Exchange of $\mathrm{Cu}$ and Cd across the sediment-water interface in the intertidal mud flats from Ria Rormosa (Portugal). Hydrobiologia, 587, pp. 147-155, 2007.

[20] Van den Berg, G.A., Loch, J.P.G, Van der Heijdt, L.M. \& Zwolsman, J.J.G., Redox processes in recent sediments of the river Meuse, The Netherlands. Biogeochemistry, 48, pp. 217-235, 2000.

[21] Huettel, M., Roy., H., Precht., E. \& Ehrenhauss., S., Hydrodynamical impact on biogeochemical processes in aquatic sediments. Hydrobiologia, 494, pp. 231-236, 2003.

[22] Rush, A. \& Huettel, M., Advective particle transport into permeable sediments - evidence from experiments in an intertidal sandflat. Limnology and Oceanography, 45(3), pp. 525-533, 2000.

[23] Sondergaad, M., Pore water dynamics in the sediment of a shallow and hypertrophic lake. Hydrobiologia, 192, pp. 247-258, 1990.

[24] Cappuyns, V. \& Swennen, R., Kinetics of elements release during combined oxidation and $\mathrm{pH}$ leaching of anoxic river sediment. Applied Geochemistry, 20(6), pp. 1169-1179, 2005.

[25] Machado, W., Carvalho, M.F., Santelli, R.E. \& Maddock, J.E.L., Reactive sulfides relationship with metals in sediments from an eutrophicated estuary in southeast Brazil. Marine Pollution Bulletin, 49(1-2), pp. 89-92, 2004.

[26] Maddock, J.E.L., Carvalho, M.F., Santelli, R.E. \& Machado, W., Contaminant metal behaviour during resuspension of sulphidic estuarine sediments. Water, Air and Soil Pollution, 118, pp. 193-200, 2007.

[27] von Mecklenburg, C. \& Lundgren, T., Control Programme for the Central Industrial Area in Atvidaberg City Including the Recipients. Compilation and Evaluation of Monitoring Records March 2002-2007, Report Envipro Miljöteknik AB \& Åtvidabergs kommun, 2007 (in Swedish).

[28] Håkansson, K., Karlsson, S. \& Allard, B., Effects of $\mathrm{pH}$ on the accumulation and redistribution of metals in a polluted stream bed sediment. The Science of the Total Environment, 87/88, pp. 43-57, 1989.

[29] Nguyen, T.L., Mobilisation of Metals from Mining Wastes and the Resuspension of Contaminated Sediments. Dissertation, Linköping Studies in Art and Science No. 430, Linköping University, Sweden, 2008.

[30] Svensson, B.H. \& Rosswall, T., In situ methane production from acid peat in plant communities with different moisture regimes in a subarctic mire. Oikos, 43, pp. 341-350, 1984.

[31] ISO 15587-1, Water quality - Digestion for the determination of selected elements in water, Part 1, Aqua regia digestion, International Standard Organization, 2002.

[32] SS-EN 12880, Characterization of Sludge - Determination of Dry Residue and Water Content, Swedish Standard Institute, 2000.

[33] SS 028112, Determination of Suspended Solids in Wastewater and their Residue on Ignition, Swedish Standard Institute, 1996.

[34] Davidson, G.R., Bennett, S.J., Beard, W.C. \& Waldo, P., Trace elements in sediments of an aging reservoir in rural Mississippi: potential for mobilization following dredging. Water, Air and Soil Pollution, 163, pp. 281-292, 2005. 
[35] Gustafsson, J.P., Visual MINTEQA Chemical Equilibrium Model, Version 2.53, Department of Land and Water Resources Engineering, Royal Institute of Technology, Stockholm, Sweden, 2004.

[36] Grimm, D., Azarraga, L., Carreira, L. \& Susetyo, W., Continuous multiligand distribution model used to predict the stability constant of $\mathrm{Cu}$ (II) metal complexation with humic material from fluorescence quenching data. Environmental Science \& Technology, 25, pp. 1427-1431, 1991.

[37] SEPA, Environmental quality criteria for lakes and watercourses, Swedish Environmental Protection Agency, 2007, www.internat.naturvardsverket.se/.

[38] Fritsche, U., Koschinsky, A. \& Winkler, A., The different diffusive transport behaviours of some metals in layers of Peru Basin surface sediment. Deep-Sea Research II, 48, pp. 3653-3681, 2001.

[39] Metzger, E., Simonucci, C., Viollier, E., Sarazin, G., Prévot, F., Elbaz-Poulichet, F., Seidel, J.L. \& Jezequel, D., Influence of diagenetic processes in Thau lagoon on cadmium behaviour and benthic fluxes. Estuarine Coastal and Shelf Science, 72, pp. 497-510. 2007.

[40] Li, Y.H. \& Gregory, S., Diffusion of ions in sea water and in deep-sea sediments. Geochimica et Cosmochimica Acta, 38, pp. 703-714, 1974.

[41] Lavery, P.S., Oldham, C.E. \& Ghisalberti, M., The use of Fick's First Law for predicting porewater nutrient fluxes under diffusive conditions. Hydrological Process, 15, pp. 2435-2451, 2001.

[42] Davranche, M., \& Bollinger, J.C., Release of metals from iron oxyhydroxides under reductive conditions: effects of metal/solid interactions. Journal of Colloid and Interface Science, 232, pp. 165-173, 2000.

[43] Davidson, W., Iron and manganese in lakes. Earth-Science Review, 34, pp. 119-163, 1993.

[44] Hyacinthe, C., Bonneville, S. \& Van Cappellen, P., Reactive iron (III) in sediments: chemical versus microbial extractions. Geochimica et Cosmoschimica Acta, 70, pp. 4166-4180, 2006.

[45] Theiss, T.L. \& Singer, P.C., Complexation of iron (II) by organic matter and its effects on iron (II) oxygenation. Environmental Science \& Technology, 8(6), pp. 569-573, 1974.

[46] Cappuyns, V., Swennen, R. \& Devivier, A., Dredged river sediments: potential chemical time bombs? A case study. Water, Air and Soil Pollution, 171, pp. 49-66, 2006.

[47] Förstner, U. \& Wittman, G.T.W., Metal Pollution in the Aquatic Environment, 2nd revised edition, Springer, 1983.

[48] Naylor, C., Davison, W., Motelica-Heino, M., Van Den Berg, G.A. \& Van Der Heijdt, L.M., Potential kinetic availability of metals in sulphidic freshwater sediments. Science of the Total Environment, 357, pp. 208-220, 2006.

[49] Stumm, W. \& Lee, G.F., Oxygenation of ferrous iron. Industrial and Engineering Chemistry, 53, pp. 143-146, 1961.

[50] Stumm, W. \& Morgan, J.J., Aquatic Chemistry: Chemical Equilibria and Rates in Natural Waters, 3rd edn, John Wiley \& Sons, Inc., 1996.

[51] James, R.E. \& Ferris, F.G., Evidence for microbial-mediated iron oxidation at a neutrophilic groundwater spring. Chemical Geology, 212, pp. 301-311, 2004.

[52] Jones-Lee, A. \& Lee, G.F., Role of iron chemistry in controlling the release of pollutants from resuspended sediments. Remediation Winter, pp. 33-41, 2005.

[53] Gerringa, L.J.A., Aerobic degradation of organic matter and the mobility of $\mathrm{Cu}, \mathrm{Cd}, \mathrm{Ni}, \mathrm{Pb}, \mathrm{Zn}$, Fe and Mn in marine sediment slurries. Marine Chemistry, 29, pp. 355-374, 1990.

[54] Bourg, A.C.M. \& Loch, J.P.G., Mobilization of heavy metals as affected by $\mathrm{pH}$ and redox conditions. Biogeodynamics of Pollutants in Soils and Sediments: Risk Assessment of Delayed and Non-linear Responses, eds W. Salomons \& W.M. Stigliani, Springer-Verlag: Berlin, pp. 87-102, 1995. 
[55] Horckmans, L., Swennen, R. \& Deckers, J., Retention and release of Zn and Cd in spodic horizons as determined by $\mathrm{pH}_{\text {stat }}$ analysis and single extractions. Science of the Total Environment, 376, pp. 86-99, 2007.

[56] Karlsson, S., Influence of Hydrochemical Parameters on the Mobility and Redistribution of Metals from a Mine Waste Deposit. Dissertation, Linköping Studies in Art and Science No. 10, Linköping University, Sweden, 1987.

[57] Salomons, W. \& Förstner, U., Metals in the Hydrocycle, Springer-Verlag: Berlin, 1984.

[58] Drever, J.I., The Geochemistry of Natural Waters: Surface and Ground Water Environments, 3rd edn, Prentice Hall Inc.: New Jersey, 1997. 